\title{
RAZVIJANJE KOMPETENTNOSTI BODOČIH UČITELJEV GEOGRAFIJE NA PRIMERU UČNE STRATEGIJE POJMOVNIH MREŽ
}

\author{
Lea Nemec, Tatjana Resnik Planinc: Razvijanje \\ kompetentnosti bodočih učiteljev geografije na \\ primeru učne strategije pojmovnih mrež. \\ Zbirka E-GeograFF 5. Znanstvena založba \\ Filozofske fakultete Univerze $v$ Ljubljani in \\ Oddelek za geografijo, 61 str. Ljubljana, 2012
}

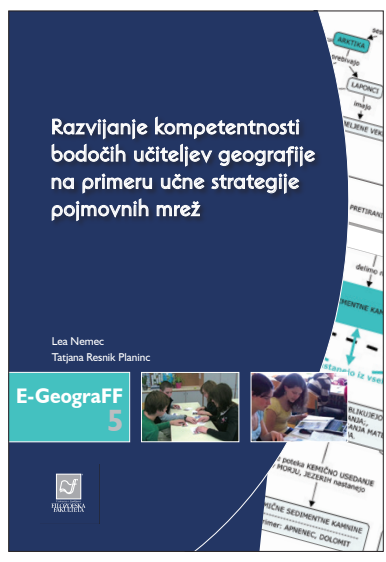

V elektronski verziji zbirke znanstvenih monografij

E-GeograFF sta konec leta 2012 izsledke svojega raziskovalnega dela objavili mag. Lea Nemec in dr. Tatjana Resnik Planinc. Avtorici z delom prinašata v slovensko geografsko izobraževanje nova spoznanja o pojmovnih mrežah kot učni strategiji, uporabni na vseh stopnjah izobraževanja in zelo dragoceni pri uveljavljanju kompetenčnega pristopa. Znanstvena monografija je posnemanja vreden rezultat povezovanja teorije in prakse, oziroma univerzitetnega izobraževanja na področju didaktike geografije ( $\mathrm{tj}$. študentov in njihovih mentoric) in pouka geografije v šoli (tj. dijakov in njihovih učiteljev). Delo se tako posveča na eni strani teoretičnim izhodiščem uporabnosti pojmovnih mrež, zlasti z vidika razvijanja kompetentnosti učiteljev geografije, na drugi strani pa preverjanju omenjene učne strategije v srednješolski praksi.

V uvodnih poglavjih je obširno predstavljen koncept kompetentnosti oziroma kompetenc učitelja na splošno, poseben poudarek pa je namenjen geografskim kompetencam. Sledi predstavitev samih pojmovnih mrež in njihove uporabne vrednosti, tako z vidika prednosti v primerjavi z drugimi grafičnimi oblikami zapisov podatkov (npr. miselnimi vzorci) kot tudi glede možnosti za doseganje vseh vrst učnih ciljev in procesnih znanj. Omenjena sistematična predstavitev je podkrepljena s konkretnimi primeri, ki omogočajo boljše razumevanje tudi bralcem brez predhodnega poznavanja tematike. Kot glavno uporabnost pojmovnih mrež avtorici izpostavljata njihovo primernost za ugotavljanje predznanja in razumevanja snovi, kakor tudi za hitrejše učenje pojmov in njihovih medsebojnih povezav. Prav slednje je za geografsko stroko še posebej pomembno. Glede na navedeno ne preseneča, da je izdelovanje pojmovnih mrež zahtevno in intelektualno zelo izzivalno za vse sodelujoče.

$\mathrm{V}$ drugem delu monografije so predstavljeni in analizirani rezultati didaktičnega eksperimenta z uporabo pojmovnih mrež v gimnazijskem geografskem izobraževanju. Avtorici sta si uvodoma zastavili kar devet raziskovalnih vprašanj in enajst delovnih hipotez, do katerih sta se lahko opredelili po opravljenem didaktičnem eksperimentu ter izčrpnem anketiranju sodelujočih - 44 študentov (bodočih učiteljev) geografije in 22 gimnazijskih dijakov. V delu so zelo nazorno nanizane ugotovitve iz obširne statistične analize odgovorov anketirancev in iskanja statističnih korelacij med odgovori/percepcijo posameznih skupin 
sodelujočih, izdatno podprte z grafičnimi prikazi. Za prihodnje izobraževanje učiteljev in nadaljnje raziskovalno delo s tega področja so vsebinsko ključne zlasti ugotovitve o pozitivni naravnanosti bodočih učiteljev do uporabe pojmovnih mrež, jasnem prepoznavanju njihove praktične vrednosti in visokem vrednotenju kompetenčnega pristopa.

Pojmovne mreže bodo kot učna strategija zagotovo našle prostor tudi v slovenskih šolah, in to ne le pri pouku geografije. Predstavljena monografija bo lahko pri tem dragoceno vodilo in pomoč. Zainteresiranim bralcem bodo koristile tudi usmeritve za nadaljnji, bolj poglobljeni študij problematike, ki jih nudi delo v obsežnem pregledu tujih in domačih strokovnih virov. Celotno delo je dostopno na spletni strani Oddelka za geografijo Filozofske fakultete (http://geo.ff.uni-lj.si/sites/default/files/e-geograff_5.pdf).

Katja Vintar Mally 